\title{
Stanisław Paździor
}

\section{Uchylanie klauzul dołączanych do wyroków w Trybunale Archidiecezji Lubelskiej}

Ius Matrimoniale 2 (8), 145-157

1997

Artykuł został zdigitalizowany i opracowany do udostępnienia w internecie przez Muzeum Historii Polski w ramach prac podejmowanych na rzecz zapewnienia otwartego, powszechnego i trwałego dostępu do polskiego dorobku naukowego i kulturalnego. Artykuł jest umieszczony w kolekcji cyfrowej bazhum.muzhp.pl, gromadzącej zawartość polskich czasopism humanistycznych i społecznych.

Tekst jest udostępniony do wykorzystania w ramach dozwolonego użytku. 
Ks. Stanisław Paździor

\section{Uchylanie klauzul dolączanych do wyroków w Trybunale Archidzieczji Lubelskiej}

\section{Wstep}

Sądy Kościelne w głównej mierze zajmują się orzekaniem czy małżeństwo zawarte w Kościele zostało ważnie czy też nieważnie zawarte. Bardzo często w prawomocnym wyroku lub dekrecie II Instancji orzekającym nieważnosć małżeństwa dołączona jest klauzula, że jedna bądź też obie strony nie mogą zawrzeć sakramentalnego zwiazzku małźeńskiego bez zgody właściwego Ordynariusza. W praktyce uchylaniem powyższych klauzul zajmują się najczęściej Sądy Biskupie, tak jest również w Archidiecezji Lubelskiej. Nakłada to na sądy nowe obowiązki. Niniejsze opracowanie ukazuje procedurę uchylania klauzul $\mathrm{w}$ tutejszym Trybunale $\mathrm{z}$ uwzględnieniem różnych sytuacji jakie mają miejsce $w$ tym wzgledzie.

\section{Pojecie klauzuli.}

Klauzula w prawie kanonicznym jest to zastrzeżenie, ograniczenie warunek $^{1}$. W Kodeksie Prawa Kanonicznego klauzula ma zastosowanie w różnych dziedzinach: przy wydawaniu aktów administracyjnych ${ }^{2}$, w przepisach o przywilejach ${ }^{3}$, w kwestiach regulujących pobożne fundacje ${ }^{4}$ a także na terenie prawa małżeńskiego ${ }^{5}$.

Gdy wyrok I Instancji orzekający nieważność małżeństwa zostanie potwierdzony w trybunale apelacyjnym czy to dekretem, czy to drugim

1 A. Pugliese, Dictionarium morale et canonicum, Romae 1962, t.I,s.697-700

Kan. 38 KPK

3 Kan.81. KPK

${ }^{4}$ Kan. 1301 \$3 KPK

5 Kan. $1077 \S^{11}$ : „Ordinarius loci propriis subditis ubique commorantibus et omnibus in proprio territorio actu degentibus vetare potest matrimonium in casu peculiari, sed ad tempus tantum, gravi de causa esque potest".

$\S 2$ : Vetito clausulam dirimentem una suprema Ecclesiae auctoritas addere potest". 
wyrokiem, ci, których małżeństwo uznano za nieważne, mogą z chwilą powiadomienia ich o dekrecie lub drugim wyroku, zawrzeć nowe związki małżeńskie, chyba, że zakaz zamieszczony w wyroku lub dekrecie, bądź ustanowiony przez Ordynariusza miejscowego zabraniałby tego ${ }^{6}$.

W ostatnich latach sądy kościelne najczęściej rozpatrują sprawy o nieważność małżeństwa $\mathrm{z}$ kan. 1095 n.2 i 3. Orzeczenie nieważności małżeństwa $\mathrm{z}$ tych tytułów połączone jest $\mathrm{z}$ reguły $\mathrm{z}$ zakazem zawierania związku małżeńskiego dla tej osoby po której stronie wystąpiła niezdolność. Niniejszy artykuł ma za cel przybliżyć okoliczności nakładania klauzul jak też problematykę związaną $\mathrm{z}$ ich uchylaniem.

Praktyka wskazuje, że w większości metropolii klauzula jest nakładana przez II Instancje w dekrecie zatwierdzającym wyrok I Instancji, a jeśli prowadzony był proces to w wyroku.

Można jednak postawić pytanie, czy taką klauzulę może nałożyć Trybunał I Instancji i jaką ma ona wówczas moc? Nie sposób jednoznacznie i w pełni tę kwestię wyjaśnić w niniejszym opracowaniu. Wydaje się jednak, że Trybunał I Instancji ma pełne prawo zamieścić w wyroku taką klauzule, jeśli sędziowie są przekonani o jej potrzebie. Dekret II Instancji w takim przypadku zatwierdzając wyrok I Instancji ipso facto zatwierdza $i$ klauzulę ${ }^{7}$. Jeśli natomiast sẹdziowie w I Instancji takiej klauzuli nie nałożą a sędziowie II Instancji są przekonani o jej potrzebie, nie tylko mogą ale powinni klauzulę wprowadzić, niezależnie od tego czy ich decyzja jest podjęta w formie wyroku czy dekretu.

Sad Metropolitalny w Warszawie, który jest Trybunałem II Instancji dla Sądu Metropolitalnego w Lublinie w swoich dekretach lub wyrokach dołącza najczęściej klauzulę w następującym sformułowaniu: „NN nie może zawrzeć sakramentalnego związku małżeńskiego bez zgody właściwego Ordynariusza, po uprzednim przedstawieniu aktualnej opinii bieglego psychiatry lub psychologa zgodnie z przepisem kan.1077 i kan. $1684 \S 1$ KPK".

6 Kan. 1684 §1: „Postquam sententia, quae matrimonii nullitatem primum declaravit, in gradu appellationis confirmata est vel decreto vel altera sententia, $\mathrm{ii}$, quorum matrimonium declaratum est nullum, possunt novas nuptias contrahere statim ac decretum vel altera sententia ipsis notificata est, nisi vetito ipsi sententiae aut decreto apposito vel ab Ordinario loci statuto id prohibeatur".

7 Szerzej o naturze dekretu zobacz: Ks. A. Dzięga, Strony sporu w kanonicznym procesie o nieważność małżeństwa, Warszawa 1994, s.83-88 
W pierwszych latach obowiązywania nowego prawa w prawomocnych dekretach lub wyrokach Sądu Metropolitalnego w Warszawie klauzula była sformułowana nieco inaczej: „NN nie może zawrzeć sakramentalnego związku małżeńskiego bez zgody właściwego Ordynariusza". Nie było więc wówczas nakazu konsultowania $z$ biegłym psychologiem lub psychiatrą decyzji Ordynariusza uchylającej klauzulę. Płynęło to prawdopodobnie $\mathrm{z}$ tego, że w sądach kościelnych nie było wystarczającej ilości odpowiednio przygotowanych bieglych psychologów i psychiatrów, wskutek czego sądy orzekały nieważnosć małżeństwa nie zasięgając opinii biegłego. Obecnie w Sądzie Metropolitalnym w Lublinie w każdej sprawie prowadzonej z tych tytułów zasięga się opinii biegłego, najczęściej psychologa ${ }^{8}$.

\section{Skutki prawne klauzuli i okoliczności ich uchylania.}

Dołączenie do wyroku klauzuli w wyżej wskazanej redakcji oznacza, że zainteresowana osoba zasadniczo nie może zawrzeć związku małżeńskiego. Zakaz płynie stąd, że okoliczności, które spowodowały niezdolność tej osoby do pierwszego małżeństwa i w konsekwencji nieważność związku, spowodują także nieważność kolejnego związku. Doświadczenie życiowe wskazuje jednak, że zarówno osobowość wielu osób podlega procesowi swoistego dojrzewania i uwarunkowania towarzyszące zawieraniu kolejnego związku mogą w sposób istotny odbiegać od uwarunkowań pierwszego związku. Dołączenie klauzuli zobowiązuje władzę kościelną do dokładnego przeanalizowania tych uwarunkowań i wyrażenia zgody na małżeństwo przed jego zawarciem. Kompetentnym do rozpatrzenia tej sprawy jest Ordynariusz wskazany w klauzuli. Ordynariuszem właściwym do uchylania klauzuli jest więc zarówno Ordynariusz miejsca stałego lub tymczasowego zamieszkania osoby zainteresowanej a także Ordynariusz miejsca zawierania małżeństwa. Należy w tym miejscu zaznaczyć, że zgoda Ordynariusza jest wymagana jedynie do godziwości a nie do ważności.

${ }^{8}$ W literaturze można spotkać opinię, że w przypadku orzeczenia nieważności małżeństwa $z$ tytułu poważnego braku rozeznania oceniającego co do istotnych praw i obowiązków małżenskkich wzajemnie przekazywanych i przyjmowanych (kan.1095 n.2) należy powoływać biegłego psychiatrę a nie psychologa - zob: W. Góralski, Kanoniczna zgoda małżeńska, Gdańsk 1991, s.54-57 
Wierni, którzy żyją po kontrakcie cywilnym, bądź teź nie będąc z nikim związani decydują się na zawarcie sakramentu małżeństwa po uzyskaniu zatwierdzenia wyroku I Instancji zwracają sie do wlaściwego Ordynariysza o uchylenie klauzuli. Prośbę swoją najczęściej argumentują udanym pożyciem w nowym związku cywilnym, wskazują swoją aktualną dojrzalosć na skutek upływu czasu lub zmiany okoliczności w jakich żyją. Ci zaś, którzy nie są z nikim związani a pragną zawrzeć katolickie małżeństwo wskazują na to, że należycie poznali swoje charaktery i swoje psychiczne możliwości wytrwania w tym związku. Kladą nacisk na uczucie jakie względem siebie żywią, a także podobnie jak w poprzednich przypadkach podkreślają upływ czasu, zmianę ich sytuacji, dojrzalsze podchodzenie do życia, zerwanie $z$ nałogiem itp.

Wszyscy natomiast zwracają uwage na dobro duchowe jakie pragną uzyskać poprzez zawarcie sakramentalnego małżeństwa.

Praktyka większości diecezji wskazuje, że przed podjęciem decyzji o uchyleniu lub podtrzymaniu klauzuli Ordynariusz zleca Sądowi Biskupiemu rozpatrzenie wszystkich okoliczności istotnych dla sprawy. Ordynariusz wryraża zgodę wówczas gdy z zebranego materiału może wyrobić sobie moralną pewność, że osoba starająca się o uchylenie klauzuli w sposób dojrzały podchodzi do praw i obowiązków małżeńskich oraz jest w stanie obowiązki te przyjąć i wypełnić we wspólnocie życia $z$ partnerem.

W Archidiecezji Lubelskiej od 2 lat powołany jest dla tych spraw wikariusz biskupi, którym jest jeden $\mathrm{z}$ wiceoficjałów ${ }^{9}$.

\section{Procedura stosowana przy uchylaniu klauzul.}

Warto bliżej spojrzeć na procedurę stosowaną przy rozpatrywaniu próśb o uchylenie klauzuli w Sądzie Metropolitalnym w Lublinie. Na podstawie czego władza kościelna przychyla się do prośby petenta i wyrabia sobie moralną pewność, że nowy związek będzie zgodny i trwały, że przeszkoda powodująca nieważnosć małżeństwa już nie istnieje?

9 Daje to konkretne korzyści gdyż wikariusz biskupi posiada władzę Ordynariusza miejsca do uchylania klauzul zgodnie z kan. 134 a jednocześnie doskonale zna uwarunkowania orzecznictwa sq̨dowego. 


\section{a) Prośba petenta}

W pierwszej kolejności bierze się pod uwagę pismo w którym zawarta jest prośba skierowana do Ordynariusza o uchylenie klauzuli. Zawarte są tam argumenty, które mają przekonać Ordynariusza, że ktoś w sposób dojrzaly i z należytym rozeznaniem podejmuje decyzję zawarcia małżeństwa. Nigdy nie praktykuje się aby na podstawie samej prośby, nawet zawierającej bardzo silne argumenty taka klauzula była uchylana.

\section{b) Przesluchanie petenta}

Po wplynięciu prośby wzywa się do Trybunału osobę proszącą wraz z jej przyszłym współmałżonkiem. Przeprowadza się przesłuchanie petenta ale bez odbierania przysiegi. Podczas tego przesłuchania proszący ma możliwość ustosunkować się do faktów znajdujących się w prawomocnym dekrecie lub wyroku, na podstawic których została orzeczona nieważność małżeństwa. Ma też okazję przekonywać władzę kościelną, że przeszkody ustąpiły calkowicie lub w bardzo znacznym stopniu. Pytania zawarte w takim przesłuchaniu informacyjnym zależą od bardzo wielu okoliczności. Wyjaśniają przede wszystkim czy przyczyna niezdolności trwa w dalszym ciągu a jeśli trwa to czy w aktualnych okolicznościach również powoduje skutek niezdolności osoby. Postępowanie wyjaśniające musi uwzględnić, ile czasu upłynęło od zawarcia picrwszego małżeństwa, czy proszący żyje w związku cywilnym, czy też nie. Jeżeli żyje w związku cywilnym to jak długo on trwa, co było głównym powodem nieważności małżeństwa, jakie stwierdzono defekty natury psychicznej, co było ich podłożem itp. Każdy przypadek jest inny i dlatego pytania będą do tego dostosowane.

W Archidiecezji Lubelskiej przyjęła się praktyka, że nie uchyla się klauzul jeżeli proszący dopiero w przyszłości ma zawrzeć małzeństwo.

\section{c) Przesiuchanie przyszłlego wspólmałżonka}

Istotnych argumentów dostarcza także przesłuchanie przyszłego współmałżonka. Zwraca się tutaj uwage na to w jakich okolicznościach doszio do zapoznania, czy druga strona zna przeszłosć petenta, czy zapoznała się $z$ prawomocnym wyrokiem i argumentami tam zawartymi? Pyta się czym zaimponowała jej druga strona? Jeżeli żyją w związku cywilnym pyta się jak układa się pożycie małżeńskie, czy osoba dotknięta klauzulą troszczy się o rodzinę, współmałżonka, dzieci, czy pracuje zawodowo, czy należycie 
wywiązuje się ze swoich obowiązków? Czy są zadowoleni z tego związku? Ma się także ustosunkować do konkretnych zarzutów zawartych w prawomocnym dekrecie lub wyroku. $\mathrm{Na}$ koniec stawia się pytanie czy popiera prośbe przyszłego współmałżonka?

Praktyka wskazuje, że cywilni współmałżonkowie petentów $z$ reguły stawiają się do Sądu i naświetlają sprawę ze swojego punktu widzenia. Oświadczenia ich są bardzo istotne i mogą nawet mieć większą wage aniżeli stwierdzenia samego petenta.

Niekiedy jednak rezygnuje się z przesłuchania narzeczonego czy narzeczonej z powodu dużej odległości zamieszkania, dalekiego wyjazdu gdy zebrany materiał pozwala wyrobić sobie moralną pewność.

\section{d) Opinia biegłego}

Po dokonaniu powyższych czynności zasięga się opinii biegłego sądowego psychologa lub psychiatry. Biegły powinien wcześniej zapoznać się przynajmniej z treścią prawomocnego dekretu lub wyroku, niekiedy z aktami sprawy a szczególnie z opinią biegłego, która tam się znajduje. Biegły zawsze przeprowadza rozmowę psychologiczną $\mathrm{z}$ osobą na której ciąży klauzula, bądź też przeprowadza badania psychologiczne (lub psychiatryczne) w zależności od trudności przypadku. W niektórych sprawach przeprowadza także rozmowę z przyszłym współmałżonkiem. Opinię sporządza na piśmie. Stwierdzając zasadność uchylenia klauzuli ma poprzeć to konkretnymi argumentami. W tym miejscu ma sį̨ szczególnie ustosunkować do opinii biegłego czy biegłych którzy brali udział $w$ procesie i wskazywali na konkretne przyczyny.

Na podstawie powyższego materiału podejmowana jest decyzja czy przychylić się do prośby czy też nie.

W ogromnej większości przypadków taka decyzja jest pozytywna. Nie zdarzyło się jeszcze żeby do sądu wpłynęła prośba o stwierdzenie nieważności małżeństwa po wcześniejszym uchyleniu klauzuli. Może to świadczyć, że decyzje o uchyleniu klauzuli są zasadne i słuszne a małżeństwa są trwałe.

Oddzielnym problemem, który jest także poruszany przy rozpatrywaniu prośby o uchylenie klauzuli jest stosunek przyszłych małżonków do posiadanego potomstwa z pierwszego małżenstwa. Szczególnie chodzi o mężczyznę, gdyż najczęściej po rozpadzie małżeństwa dzieci pozostają przy matce. Jest to okazja aby przypomnieć o obowiązku katolickiego wychowania dzieci i otoczenia ich należytą troską i miłością. Jest to też okazja aby upewnić się 
czy petent ma kontakt z dzieckiem, a jeżeli nie, czy to nie jest zawinione, czy systematycznie płacone sq̨ alimenty ? Zaniedbanie na tym odcinku może być powodem odmówienia uchylenia klauzuli do czasu gdy w tej dziedzinie nie zostaną naprawione zaniedbania. Powyższą kwestię powinien również uwzględnić biegły sądowy.

\section{Problematyka prawna związana $\mathrm{z}$ uchylaniem klauzul.}

Omawiając zagadnienie uchylania klauzul warto spojrzeć bliżej na kilka typowych problemów przed którymi staje Ordynariusz podejmując tę decyzję. Problemy z tym związane można podzielić na kilka grup. Jako kryterium podziału przyjmuję stopień trudności w wyrobieniu sobie moralnej pewności co do zasadności uchylenia klauzuli. Trudności te wynikają ze specyficznych okoliczności życiowych w jakich aktualnie znajduje się osoba prosząca o uchylenie klauzuli. Z praktyki Archidiecezji Lubelskiej wynika, że typowymi okolicznościami są: wieloletni związek cywilny, długi okres życia samotnego, alkoholizm, bliskość czasowa obu związkỏw, odmówienie uchylenia klauzuli.

\section{a) Wieloletni związek cywilny}

Do pierwszej grupy w której takie decyzja jest stosunkowo najłatwiejsza będą należały te przypadki, gdy ktoś chce zawierać małżeństwo po dość đługim okresie czasu jaki upłynął od poprzedniego małżeństwa a jednocześnie żyje już przez wiele lat w ,udanym" związku cywilnym. Oto konkretny przykład na taką okoliczność.

NB zawarł małżeństwo w $1960 \mathrm{r}$. Małżeństwo trwało, zaledwie miesiąc czasu. Zostało uznane za nieważne $\mathrm{z}$ tytułu niezdolności obu stron do podjęcia istotnych obowiązków małżeńskich z przyczyn natury psychicznej. Żona petenta była młodsza o 11 lat, petent miał natomiast 30 lat, był samotny i wstydliwy. Biegły stwierdził u petenta niedojrzałość emocjonalną (cechy niedojrzałości społecznej, problemy adaptacyjne do tego stopnia, że sytuacje nowe automatycznie stawały się trudnymi a nawet nieprzezwycieżonymi). Trybunał w swoim dekresie zabronił petentowi zawierania związku małżeńskiego ${ }^{10}$.

\footnotetext{
10 Akta Sądu Metropolitalnego w Lublinie Nr 4326/95 - dalej ASML
} 
Kilka lat potem petent zawarł kontrakt cywilny. O zdjęcie klauzuli wnosił w 35 lat po zawarciu tego małzeństwa, drugi związek cywilny przetrwał 32 lata. Petent zeznał, ze ten związek jest zgodny i udany, nie było w nim większych problemów. Strony wychowały potomstwo po katolicku. Cywilna żona petenta potwierdziła fakt zgodnego pożycia stron. Biegły jednoznacznie stwierdził dojrzałą osobowość petenta.

W tym miejscu rodzi się pytanie czy jest sens dodawać klauzulę w przypadku jak powyższy. $Z$ akt sprawy prowadzonego procesu a także $\mathrm{z}$ opinii biegłego wynika nie tylko zasadność tytułu niezdolności petenta do podjęcia istotnych obowiązków małżeńskich w czasie zawierania małżeństwa ale także jaką osobowość prezentuje aktualnie. Jeśli wiadomo, że przez wiele lat petent żyje w zgodnym związku, dzieci zostały wychowane po katolicku, zależy mu na uregulowaniu spraw wobec Kościoła (wcześniej nie mógł tego uczynić ze względu na brak tych tytułów) można odstąpić od nakładania klauzuli.

W Sądzie Metropolitalnym w Lublinie zdarza się to, chociaż oczywiście bardzo rzadko.

W takim przypadku dolączając klauzulę można ewentualnie zrezygnować $z$ wymogu zasięgnięcia opinii bieglego, gdyż i bez takiej opinii sprawa jest dostatecznie wyjaśniona.

\section{b) Dlugi okres życia samotnego}

Druga grupa dotyczy tych osób, które wiele lat temu zawarły małżeństwo, jednak przez ten czas $z$ nikim się nie związały. Oto przykład.

Petent zawarł małżeństwo w $1974 \mathrm{r}$. Małżeństwo trwało około 4 lat. Została orzeczona jego nieważność $\mathrm{z}$ tytułu poważnego braku rozeznania oceniającego co do istotnych praw i obowiązków małżeńskich wzajemnie przekazywanych i przyjmowanych po jego stronie. Prawomocny dekret uzasadnia to następująco: ,petent pochodził z rodziny rozbitej, w młodości wychowywany przez babcię, gdyż ,przeszkadzał" matce, wcześnie zaczął spożywać alkohol, współżył z wieloma kobietami, zupełnie nie zdawał sobie sprawy z obowiązków jakie na siebie przyjmuje decydując się na małżeństwo. Już w piątym miesiącu po ślubie miał dość małżeństwa, okazal się bardzo złym mężem. „Do prawomocnego dekretu została dołączona klauzula ${ }^{11}$.

11 ASML 4147/93 
Po wielu latach samotnego życia spotkar kobietę z którą chciałby zawrzeć sakrament małżeństwa. Należy tutaj zaznaczyć, że on właśnie występował wcześniej o stwierdzenie nieważności swojego małżeństwa.

Obecnie tak uzasadnia swoją dojrzałość: Od tamtego czasu upłynęło już 22 lat, obecnie jestem zupełnie innym człowiekiem, dojrzalę podchodzę do życia. Obecną narzeczoná poznalem 4 lata temu, spotykamy się dość często, planujemy ze sobą zawrzeć sakrament małżeństwa. Na dziecko z poprzedniego malżeństwa płace alimenty. Narzeczona petenta tak ocenia ich znajomość: myślę, że należycie poznaliśmy swoje charaktery, ujął mnie dojrzałością życiową. Uważam, że sakrament małżeństwa będzie udany i trwały. Biegły psycholog po przeprowadzeniu rozmowy psychologicznej stwierdził, iż obecnie petent nie przejawia cech zaburzonej osobowości.

Wyrabiając sobie moralną pewność wzięto pod uwage głównie czas jaki upłynął od tamtego małżeństwa, zmiany jakic dokonały się $w$ psychice petenta, dość długi okres znajomości z obecną narzeczoną, troska o dziecko, pozytywny stosunek do wiary co znalazło potwierdzenie w opinii biegłego psychologa. Tego rodzaju przypadki nie należą do zbyt trudnych.

\section{c) Alkoholizm}

Inną grupą starających się o uchylenie klauzuli będą ci, których makżenstwo rozpadło się $\mathrm{z}$ powodu ich alkoholizmu. Takich przypadków w naszej rzeczywistości jest bardzo wiele. Oto konkretny przykład.

NR zawarł małżeństwo w 1983 r Małżeństwo trwało przeszło 4 lata. Została orzeczona nieważność małżństwa $\mathrm{z}$ tytułu niezdolności pozwanego-petenta do podjęcia istotnych obowiązków małżeńskich. W prawomocnym dekrecie czytamy: ,petent jeszcze przed ślubem miał opinię człowieka nadużywającego alkohol. Alkoholizm nasilił się zaraz po ślubie. Alkoholizm potwierdzają wszyscy świadkowie a biegły psycholog stwierdził niedojrzałą osobowosć petenta-charakteropatia alkoholowa". Konsekwencją prawomocnego dekretu była dołączona klauzula ${ }^{12}$.

Obecnie petent chce zawrzeć sakramentalne małżeństwo. W piśmie do Ks. Arcybiskupa i w zeznaniu informacyjnym oświadczyl: „od 16.I.1993 r. jestem calkowitym abstynentem. To była moja decyzja, wtedy w pełni przekonałem się, że alkohol do niczego dobrego nie prowadzi. Obecną narzeczoną poznałem półtora roku temu. Planujemy zawrzeć sakrament

12 ASML 4216/94 
małżeństwa. Uważam, że małżeństwo które zawrę będzie udane" Narzeczona petenta zeznała: „spotykamy się ze sobą codziennie, darzymy się uczuciem, obecnie petent jest całkowitym abstynentem. Takim był już jak go poznałam. Uważam, że do nałogu nie powróci gdyż dużo się zmienil”.

Alkoholizm pozwanego zdegenerował jego psychikę i doprowadził do rozpadu małżeństwa, natomiast jego obecna abstynencja od dość dawna i mająca początek jeszcze przed poznaniem narzeczonej wyraźnie przemawia za tym, że petent jest obecnie innym czlowiekiem, bez nałogu i prawdopodobnie dojrzałym do zawierania małżeństwa.

W tej sytuacji rola biegłego psychologa czy psychiatry tylko pozornie nic istotnego nie wnosi. Owszem, istnieje moralna pewność, że petent nie jest uzależniony od alkoholu ale rodzi się inne pytanie, czy wcześniejszy alkoholizm nie zdegradował jego psychiki w takim stopniu, że nie będzie w stanie podjąć istotnych obowiązków małżeńskich. W opinii biegłego ma to być uwzględnione. Gdy biegły nie zgłasza w tym względzie zastrzeżeń dopiero wtedy ustaje poważna wątpliwość i rodzi się moralna pewność. Same oświadczenia stron, chociaż zgodne $w$ tym przypadku nie wystarczą. W konkretnej sytuacji klauzula została uchylona, gdyż biegły po przebadaniu petenta nie stwierdził cech zaburzonej osobowości.

\section{d) Bliskość czasowa obu związków}

Praktycznie jednak najwięcej jest przypadków gdy od zawarcia małżeństwa do chwili starania się o uchylenie klauzuli upłynęło niezbyt wiele czasu (kilka lat). Bardzo często strona powodowa w której tkwila przyczyna nieważności małżeżnstwa rozpoczynając proces kościelny ma już kogoś innego. $Z$ chwilą zakończenia sprawy uzyskania prawomocnej decyzji chce jak najszybciej zawrzeć sakrament małżenstwa. W takiej sytuacji opinia biegłego staje się bardzo istotna, zwłaszcza wtedy gdy osoba starająca się o uchylenie klauzuli nie zawierała związku cywilnego. Rodzi się bowiem poważna wątpliwosć czy i to małżeństwo nie rozpadnie się? Na biegłym, jego fachowości i uczciwości będzie w dużym stopniu opierał się ten, który decyduje w tej sprawie. Jak biegły psycholog uzasadnia w takim przypadku czyjąś dojrzałosć niech posłuży konkretny przykład.

AK zawarła małżeństwo w $1989 \mathrm{r}$. Wspólnota stron trwała półtora roku. Po przeprowadzonym procesie została orzeczona nieważność małżeństwa $\mathrm{z}$ tytułu niezdolności obu stron do podjęcia istotnych obowiązków małżeńskich. Po otrzymaniu prawomocnego dekretu, w którym była dołączona 
klauzula petentka wniosła prośbę o jej uchylenie, gdyż od trzech miesięcy żyje w nowym związku cywilnym. Prawomocny dekret stawia następujące zarzuty: „petentka oszukała przyszłego meża, że jest z nim w ciąży, już w dniu ślubu płakała i wyrzucała mężowi "nie wiem po co wyszłam za niego", w małżeństwie ciągle byly kłótnie, strony nie były zdolne do kompromisu. Biegły psycholog stwierdzil niedojrzałą osobowość petentki wskazując na egocentryzm, bezkompromisowość, ograniczoną zdolność do przejawiania i wyrażania uczuć wyższych, brak zdolności modulowania i powściągania reakcji emocjonalnych, tendencję do wycofywania się po pierwszych trudnościach i niepowodzeniach"13.

W postępowaniu informacyjnym petentka zeznała: „do tamtego związku nie powinno dojść, czuje się winna rozpadu tego małżeństwa, obecnego cywilnego męża poznałam około 2 lata temu, nawzajem darzymy się uczuciem, przed nim nic nie kryję, między nami nie ma nieporozumień, chcieliśmy zawrzeć sakrament małżeństwa".

Cywilny mąż oświadczyl: „darzę ją uczuciem, okazała się szczera, bezpośrednia, uważam, że nasze małżeństwo będzie udane".

W takiej sytuacji jak wyżej zostało zaznaczone bardzo ważna jest opinia biegłego. W konkretnej sprawie czytamy: „w wyniku przeprowadzonego wywiadu psychologicznego stwierdzam, iż w chwili obecnej badana nie wykazuje cech osobowości niedojrzałej. Swojego męża zna od 2lat,. uważam, że zna go dobrze i że jest on czlowiekiem godnym zaufania i dającym jej oparcie psychiczne oraz poczucie bezpieczeństwa. Decyzję na zawarcie związku małżeńskiego podjęli wspólnie kierując się uczuciem miłości i w peIni zdając sobie sprawę z obowiązków jakie na siebie przyjmują. Wspólnie z mężem tworzy związek partnerski, wspólnie podejmują decyzję i wspólnie dążą do ich realizacji. Plany na przyszłość posiadają dojrzałe i realistyczne. Konflikty i problemy dnia powszedniego rozwiązują w sposób konstruktywny, spokojnie stawiając im czoła a nie uciekając przed nimi".

Tak scharakteryzowana aktualna osobowość petentki dokonana przez biegłego była główną podstawą do uchylenia klauzuli.

13 ASML 4231/94 


\section{e) Omówienie uchylenia klauzuli}

Najtrudniejsze przypadki przy uchylaniu klauzuli mamy wtedy gdy przyczyny zaburzonej osobowości mają charakter stały. Wówczas praktycznie cały cieżar argumentacji spada na biegłego. Oto konkretny przykład.

NR zawarł malzeństwo w $1973 \mathrm{r}$. Małżeństwo trwalo przeszło 3 lata. Zostało uznane za nieważne $\mathrm{z}$ tytułu niezdolności do podjeccia istotnych obowiązków małżenskich po stronie petenta. Petent żyje od wielu lat w nowym związku cywilnym, $\mathrm{z}$ tego związku są dzieci.

Uzasadnienie tytułu nieważności bylo następujące: „Petent w dzieciństwie przeszedı porażenie opon mózgowych, po ślubie często nadużywal alkoholu-potwierdzają to zeznanie świadków. Biegły psycholog stwierdził u petenta cechy niezintegrowanej i niedojrzałej osobowości. Biegły nie stwierdził u niego zaburzeń psychicznych ale problem ten już dostrzegar'"14.

Po uregulowaniu spraw w sądach kościelnych petent zwrócil się z prośbą o uchylenie klauzuli. Oświadczył, że jego związek cywilny jest udany. Natomiast cywilna żona petenta zeznała zupełnie co innego. Stwierdziła, że związek jest nieudany, nieszczęśliwy dla niej, uważa petenta za chorego psychicznie, bardzo się go boi. Związek jednak trwa nadal ze względu na dzieci, w przyszłości myśli od niego cdejść. Przy tym bardzo prosiła aby o tym nie dowiedział się petent, gdyż boi się o swoja przyszłość gdyby on znał jej prawdziwy pogląd na temat jego i ewentualnego $z$ nim małżenstwa.

Biegły psycholog nic znając zdania cywilnej żony petenta (nie zostało $\mathrm{mu}$ to zakomunikowane aby jego ocena była jak najbardziej obiektywna) po analizie materiału dowodowego zebranego w I Instancji, analizie dekretu oraz po badaniu psychologicznym petenta wydał następującą opinię: „U w/w zaznacza się tendencję do instrumentalnego traktowania innych osób oraz manipulowania nimi, a także egocentryczne dażenie do realizacji własnych celów i potrzeb - co ogranicza jego zdolność do podjęcia i skutecznego wypełnienia istotnych obowiązków malżenskich. Można także stwierdzić u niego brak rozeznania oceniającego co do istotnych praw i obowiązków małżeńskich wzajemnie przekazywanych i przyjmowanych".

Petentowi zakomunikowano stanowisko biegłego sądowego i oczywiście klauzula nie została uchylona. Nie było potrzeby wspominania mu o stanowisku jego cywilnej żony.

${ }^{14}$ ASML 3897/92 
Powyższy przypadek ukazuje jak bardzo pomocną jest rzeczą obecność biegłego sądowego w dziedzinie uchylania klauzul, zarówno na płaszczyźnie merytorycznej jak i psychologicznej.

\section{Uwagi końcowe}

Podsumowując powyższe rozważania można stwierdzić ogólnie, że procedura uchylania klauzul służy ludziom, którzy znaleźli się $w$ takiej sytuacji. Małżeństwa zawarte w następstwie uchylenia klauzuli sq trwałe i przynoszą bardzo konkretne korzyści duchowe.

Problemem natomiast dyskutowanym dość często pomiẹdzy osobami nie znającymi tych spraw od wewnątrz i nie uwzględniającymi pełnej argumentacji: kanonicznej i psychologicznej jest kwestia następująca: czy decyzje o uchylaniu klauzuli zabraniającej zawarcia związku małżeńskiego osobie która byla uznana za niezdolną do małzeństwa $z$ jakiegoś powodu i której małżeństwo uznano dlatego za nieważne, nie jest zaprzeczeniem samej istocie wyroku I Instancji oraz dekretu lub wyroku II Instancji?

Dyskutuje się także druga kwestię. Skoro biegly psycholog $w$ trakcie procedury uchylającej daje opinię pozytywna o tej osobie a poprzednio ta sama osoba otrzymała opinię negatywną od biegłego, tzn. że jedna $\mathrm{z}$ tych opinii jest błędna. Twierdzi się w tych dyskusjach, że jeśli aktualna opinia jest poprawna tzn., że pierwsza jest błędna i w konsekwencji wyrok orzekający nieważność małżeństwa jest niesprawiedliwy a pierwsze małżeństwo jest nadal ważne.

Jeśli zaś pierwsza opinia była pozytywna to niezdolność trwa nadal i nie ma możliwości uchylenia klauzuli.

Powyższa argumentacja pozornie jest bardzo logiczna. Opiera się jednak na zasadniczym nieporozumieniu. Rzecz dotyczy zupełnie innego czasu, a w międzyczasie mogło się wiele dokonać. Wyrok zawsze dotyczy konkretnego kościelnego małżeństwa. Oznacza to, że sędziowie osiągnęli moralną pewność odnośnie konkretnego związku.

Przypuszczają też sẹdziowie, że ta sama osoba może mieć trudności ze stworzeniem pełnej wspólnoty również $z$ innymi osobami. Jest to również tylko przypuszczenie a nie pewność moralna. Dlatego uchylenie klauzuli poprzedzające odpowiednią procedurą wyjaśniająca absolutnie nie stoi w sprzeczności z wcześniejszymi decyzjami sędziowskimi. 